\title{
What we say to families of intensive care unit patients - do they understand?
}

\author{
S Barbosa ${ }^{1 *}$, A llchenko ${ }^{1}$, A Carmo ${ }^{1}$, F Fernandes ${ }^{1}$, S Nascimento ${ }^{1}$, C Granja ${ }^{1,2,3}$ \\ From ESICM LIVES 2015 \\ Berlin, Germany. 3-7 October 2015
}

\section{Introduction}

Effective communication between physicians, nurses and the patient's representatives in intensive care unit (ICU) is a vital component of quality of care.

\section{Objectives}

To evaluate the communication between ICU patient's representatives and caregivers and identify factors associated with poor comprehension using a protocol previously described [1].

\section{Methods}

Prospective observational study running from 15 October 2014 to 15 March 2015. Included all patients who stayed for more than 2 days and had at least one visit in the first 5 days of ICU stay. The investigators applied three questionnaires: the representative (a relative or a friend that was designated by the patient or by the family and that was present in the first physician-family meeting); the physician that met the family at the admission; the nurse who cared the patient for more than 2 days.

\section{Results}

Of the 207 patients admitted in this period, 135 stayed more than 2 days in the ICU. Of these, we were able to enroll the family in 63 of them (47\%). Forty-five patients $(71 \%)$ had more than 50 years, $52 \%$ were male, $71 \%$ were married, $84 \%$ were Portuguese and $78 \%$ had comorbidities. Median SAPS II was 47 and median ICU length of stay was 11 days. Main reasons for ICU admission were shock (35\%), respiratory infection with acute respiratory failure (26\%) and multiple trauma (13\%). Thirty-eight of the representatives (60\%) were

${ }^{1}$ Centro Hospitalar do Algarve, Hospital de Faro, Emergency and Intensive Care Department, Faro, Portugal

Full list of author information is available at the end of the article female, $86 \%$ were Portuguese, $38 \%$ were sons, $76 \%$ were employed and $24 \%$ had only primary school education. The first physician-family meeting duration was between 10 and 20 minutes in $62 \%$ and occurred in a room used only for this purpose in $43 \%$. Failure to comprehend the diagnosis, prognosis or treatment was noted in 39 representatives (62\%); $25 \%$ of the representatives did not understand the diagnosis, $49 \%$ did not understand the treatment and $37 \%$ did not understand the prognosis. Factors significantly associated with poor comprehension were patient comorbidities, age of the representative more than 50 years and first physician-family meeting duration less than 10 minutes. Also, lower number of daily visits and Portuguese nationality, although not reaching statistical significance, exhibited a trend to be associated with poor comprehension.

\section{Conclusions}

In this study poor comprehension was found in $62 \%$ of the representatives, which is in line with previous studies [1]. A high number of comorbidities, first physician-family meeting duration less than $10 \mathrm{~min}$, representatives older than 50 years, were the factors significantly associated to poor comprehension. This study draws our attention to the need to improve communication with the families and to try to identify patients and families at high risk of poor comprehension.

\section{Authors' details \\ ${ }^{1}$ Centro Hospitalar do Algarve, Hospital de Faro, Emergency and Intensive Care Department, Faro, Portugal. ' ${ }^{2}$ niversity of Algarve, Department of Biomedical Sciences and Medicine, Faro, Portugal. ${ }^{3}$ Faculty of Medicine of Porto, CINTESIS, Porto, Portugal.}

Published: 1 October 2015 (c) 2015 Barbosa et al.; This is an Open Access article distributed under the terms of the Creative Commons Attribution License (http:// creativecommons.org/licenses/by/4.0), which permits unrestricted use, distribution, and reproduction in any medium, provided the original work is properly cited. 


\section{Reference}

1. Azoulay E, Chevret S, Leleu G, Pochard F, Barboteu M, Adrie C, et al: Half the families of intensive care unit patients experience inadequate communication with physicians. Crit Care Med 2000, 28(8):3044-3049.

doi:10.1186/2197-425X-3-S1-A471

Cite this article as: Barbosa et al.: What we say to families of intensive care unit patients - do they understand? Intensive Care Medicine Experimental 2015 3(Suppl 1):A471.

\section{Submit your manuscript to a SpringerOpen ${ }^{\circ}$ journal and benefit from:}

- Convenient online submission

- Rigorous peer review

- Immediate publication on acceptance

- Open access: articles freely available online

- High visibility within the field

- Retaining the copyright to your article

Submit your next manuscript at $\gg$ springeropen.com 